\title{
Relationships of apoptotic signaling mediated by ceramide and TNF- $\alpha$ in U937 cells
}

\author{
Nicos Karasavvas ${ }^{1}$ and Zahra Zakeri ${ }^{\star, 1}$ \\ 1 Department of Biology, Queens College and Graduate Center of the City \\ University of New York, Flushing, New York 1367-1597, USA \\ * corresponding author: Z. Zakeri, Queens College and Graduate Center of the \\ City University of New York, Flushing, NY 1367-1597. tel: 718-997-3417; fax: \\ 718-997-3429
}

Received: 2.8.98; revised 9.11.98; accepted 25.11.98 Edited by R.A. Knight

\begin{abstract}
It is commonly assumed that ceramide is a second messenger that transduces signaling leading to apoptosis. We tested this hypothesis by investigating the role of ceramide in TNF- $\alpha-$ initiated apoptotic signaling using the histiocytic lymphoma cell line U937. We found considerable differences between cell killing by TNF- $\alpha$ and by ceramide. U937 cells treated with TNF- $\alpha$ are committed early and irreversibly to the apoptotic pathway and start to die 90 min after treatment. U937 cells treated with ceramide start to die $12 \mathrm{~h}$ after the initial treatment. The cell death signaling initiated by TNF- $\alpha$ is transduced within minutes of exposure to TNF- $\alpha$ and it is irreversible. Exogenous ceramide increases the intracellular level of ceramide rapidly, significantly, and well above the physiological levels, within minutes, but cellular commitment to death does not occur until after the first $6 \mathrm{~h}$ of incubation. Furthermore, the endogenous ceramide in U937 cells treated with TNF- $\alpha$ increases well after the commitment to the apoptotic pathway. The differences between ceramide and TNF- $\alpha$ in the kinetics and the commitment to the apoptotic pathway suggest that, (a) ceramide is not a second messenger in the apoptotic signaling of TNF- $\alpha$, (b) ceramide elevations, in TNF- $\alpha$ treated cells, are a consequence rather than a cause of apoptosis and (c) exogenously added ceramide and TNF- $\alpha$ kill cells via different pathways.
\end{abstract}

Keywords: apoptosis; ceramide; tumor necrosis factor alpha; sphingolipids; cell death signaling

Abbreviations: TNF- $\alpha$, tumor necrosis factor alpha; $\mathrm{D}-\mathrm{e}-\mathrm{C}_{8}-\mathrm{Cer}, \mathrm{N}$ octanoyl-D-erythro-sphingosine; D- $t-\mathrm{C}_{8}$-Cer, $N$-octanoyl-D-threosphingosine; DG kinase, diacylglycerol kinase

\section{Introduction}

Ceramide is a sphingolipid generated along with phosphocholine upon the hydrolysis of sphingomyelin by neutral (magnesium-dependentand-independent) and acidicsphingomyelinases. ${ }^{1-6}$ The discovery of multiple ceramide targets that are involved in cell growth, cell cycle, cell death, HIV replication, IL-6 production and differentiation, suggests the physiological importance of ceramide in cellular homeostasis and metabolism. ${ }^{3,7-14}$

One important role of ceramide is presumed to be the regulation and activation of the cell death pathway. ${ }^{6,11,12 \text {, }}$ $15-18$ This assumption is based on the following criteria: (a) The endogenous ceramide concentration increases under various conditions that lead to cell death, for instance, ionizing radiation, ${ }^{19}$ withdrawal of serum, ${ }^{10}$ ultraviolet- $C$ radiation, heat shock, ${ }^{18}$ chemotherapeutic agents such as daunorubicin $^{20}$ and oxidative stress. ${ }^{21}$ (b) Addition of synthetic ceramide analogs to a variety of cells in culture (such as U937 cells) induces apoptosis. ${ }^{10-12,15}$ (c) Lipids structurally related to ceramide, such as oleic acid, dioctanoylglycerol and phorbol 12-myristate 13-acetate and dihydroceramides fail to kill cells. ${ }^{15,22}$ The specificity of ceramide induced apoptosis suggests that ceramide is a second messenger in the activation of cell death.

Several laboratories have presented evidence that ceramide mediates the apoptotic signaling by TNF- $\alpha$ and Fas. $^{5,6,15,16,22-24}$ These two members of the TNF superfamily are major components in the physiological regulation of apoptosis. ${ }^{25-28}$ TNF- $\alpha$ association with its receptors generates ceramide, ${ }^{29,30}$ suggesting that ceramide mediates the cytotoxicity of TNF- $\alpha .^{15,18,22,31}$ This hypothesis is supported by studies showing that exogenously added synthetic ceramides, which bypass the ligand-receptor cell signaling, mimic the cytotoxicity of TNF- $\alpha$ and kill cells.

Although ceramide elevation has been shown in many instances of cell death, it is still possible that the rise in ceramide is a consequence rather than a cause of apoptosis. To examine this possibility we: (a) investigated the kinetics by which ceramide and TNF- $\alpha$ kill cells (b) determined the time at which ceramide and TNF- $\alpha$ treated cells commit themselves to the apoptotic pathway and (c) established the time at which ceramide is generated in relation to the commitment to the apoptotic pathway.

\section{Results}

\section{Kinetics of TNF- $\alpha$ and D-e-C $\mathrm{C}_{8}$-Cer induced cell killing}

We examined the time required by TNF- $\alpha$ and exogenous D$e-\mathrm{C}_{8}$-Cer to induce apoptosis in U937 cells. We postulated that if the ceramide generated by TNF- $\alpha$ mediates apoptosis in U937 cells, then addition of exogenous ceramide should activate the apoptotic pathway with timing similar to that of TNF- $\alpha$.

U937 cells were exposed to $10 \mathrm{ng} / \mathrm{ml}$ of $\mathrm{TNF}-\alpha$ for 30 , $60,90,120,180$ and $360 \mathrm{~min}$. At the end of the incubation period equal numbers of cells were lysed and the degree of apoptosis was assessed by agarose gel electrophoresis of 
the isolated low mass DNA. DNA fragments were first detected at $90 \mathrm{~min}$ (Figure 1A). DNA fragmentation was thereafter detected in cells treated for as long as $360 \mathrm{~min}$ (Figure 1A). Contrary to the rapid induction of cell death by TNF- $\alpha$, ceramide required incubation times that were substantially higher than those of TNF- $\alpha$ to kill U937 cells. Using agarose gel electrophoresis of low molecular mass DNA, we detected nucleosomal fragments in cells treated with $10 \mu \mathrm{M}$ of $\mathrm{D}-e-\mathrm{C}_{8}$-Cer only after 12 and $18 \mathrm{~h}$ (Figure $1 \mathrm{~B})$. We did not detect nucleosomal fragmentation in cells treated with $\mathrm{D}-e-\mathrm{C}_{8}-\mathrm{Cer}$ for 3 and $6 \mathrm{~h}$ (Figure 1B). Thus, the time required for killing $U 937$ cells is substantially less for TNF- $\alpha$ than for $\mathrm{D}-e-\mathrm{C}_{8}-\mathrm{Cer}$. These observations were confirmed with nuclear staining of chromatin using the DNA fluorochrome bis-benzimide (data not shown).

A possible explanation for the difference in the kinetics of cell killing by TNF- $\alpha$ and $\mathrm{D}-e-\mathrm{C}_{8}$-Cer could be that TNF- $\alpha$ increases the ceramide levels rapidly, whereas exogenously added ceramide enters U937 cells more slowly. We therefore, measured the intracellular ceramide level in cells treated with TNF- $\alpha$ and compared this level to the ceramide level of cells treated with $\mathrm{D}-\mathrm{e}-\mathrm{C}_{8}$-Cer. U937 cells were treated with $10 \mathrm{ng} / \mathrm{ml}$ of TNF- $\alpha$ for $2,7.5,30,60,180$ and $360 \mathrm{~min}$. At the end of each incubation time the intracellular level of ceramide was measured as described in Materials and Methods. We did not detect ceramide elevations in cells treated with TNF- $\alpha$ for the first $60 \mathrm{~min}$. We detected a small $(0.02$-fold) increase in ceramide over the control after $1 \mathrm{~h}$ of incubation with TNF- $\alpha$ (Figure 2A), $30 \mathrm{~min}$ before

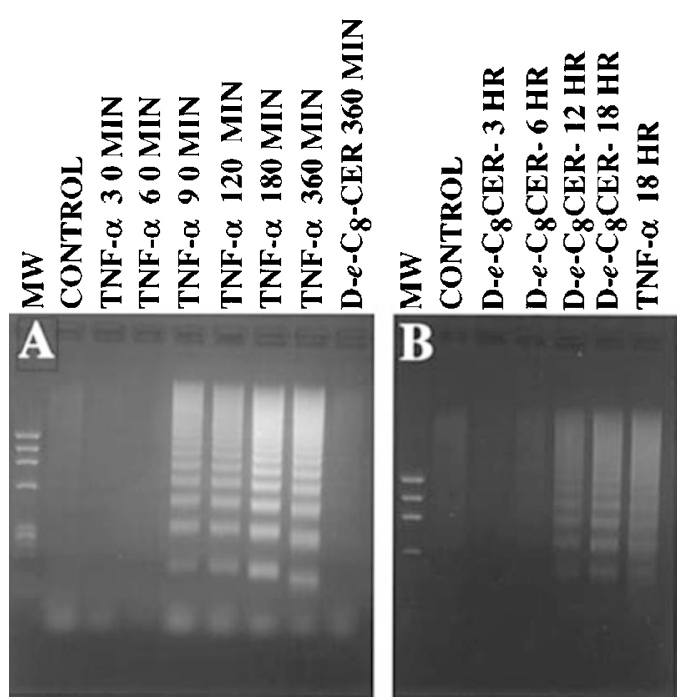

Figure 1 Time course of DNA fragmentation induced by TNF- $\alpha$ and D-e-C Cer. Agarose gel electrophoresis and ethidium bromide staining of low molecular mass DNA extracted from U937 cells $\left(5 \times 10^{6}\right)$ treated with $10 \mathrm{ng} / \mathrm{m}$ TNF- $\alpha$ for $30,60,90,120,180$ and 360 min or with $10 \mu \mathrm{M}$ D-e-C - Cer for 3,6 12 and $18 \mathrm{~h}$. (A) DNA fragmentation ladders from U937 cells treated with TNF$\alpha$ for $30,60,90,120,180$ or $360 \mathrm{~min}$. The last lane contains DNA from U937 cells treated with $10 \mu \mathrm{M} \mathrm{D}-e-\mathrm{C}_{8}-\mathrm{Cer}$ for $360 \mathrm{~min}$. Cells incubated with media containing $1 \%$ fetal bovine serum for 360 min were used as control. (B) DNA fragmentation ladders from U937 cells treated with $D-e-C_{8}-C e r$ for $3,6,12$ and $18 \mathrm{~h}$. The last lane contains DNA from cells treated with TNF- $\alpha$ for $18 \mathrm{~h}$. Cells treated with $0.1 \%$ ethanol were used as control. MW, molecular mass markers ( $\phi$ X174 DNA/HaellI)
DNA fragmentation was detected (Figure 1A). The ceramide continued to increase gradually and by the end of a $6 \mathrm{~h}$ incubation time the ceramide level increased 0.45 fold above the control (Figure 2A).

We next measured the rise in the intracellular ceramide in cells treated with $\mathrm{D}-e-\mathrm{C}_{8}-\mathrm{Cer}$. U937 cells were treated with $10 \mu \mathrm{M}$ D-e-C $\mathrm{C}_{8}$-Cer for $2,7.5,15,30,60$ and $180 \mathrm{~min}$ and at the end of each incubation time the ceramide level was quantitated as above. In $\mathrm{D}-e-\mathrm{C}_{8}$-Cer treated cells, ceramide increases rapidly and within the first 2 min of incubation we detected a significant increase (0.6-fold) over the control (the ceramide concentration in control cells was about 50 pmoles $/ 1 \times 10^{6}$ cells) untreated cells, (Figure $2 \mathrm{~B}$ ). With a 15 and a 60 min incubation time the increase in ceramide was approximately 2- and 8-fold above the control, respectively (Figure $2 \mathrm{~B}$ and $\mathrm{C}$ ). At the end of $\mathrm{a}$ $3 \mathrm{~h}$ incubation the levels of ceramide rose 18-fold above the control and beyond the linear range of ceramide
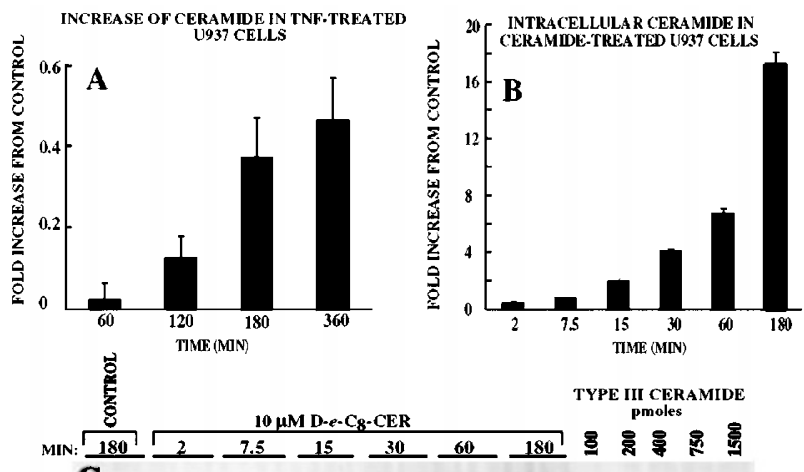

C
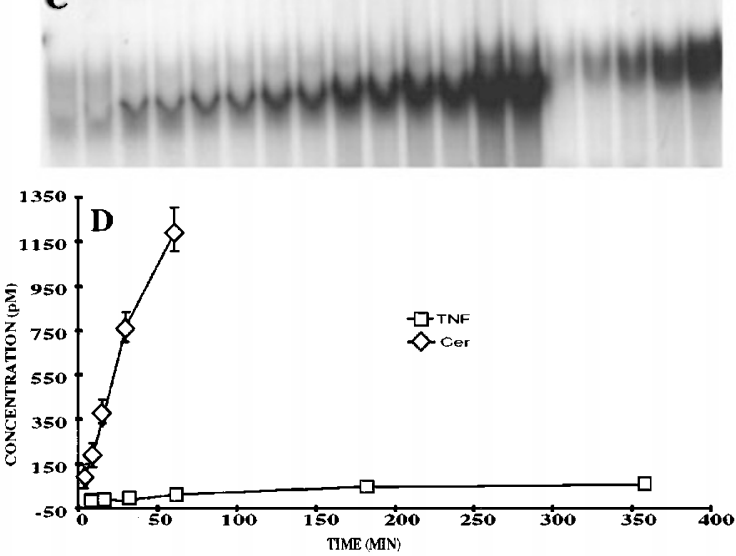

Figure 2 Endogenous levels of ceramide in cells treated with TNF- $\alpha$ or D-e$\mathrm{C}_{8}$-Cer. Labeling and quantitation of the intracellular ceramide levels in U937 cells treated with $10 \mathrm{ng} / \mathrm{ml} \mathrm{TNF}-\alpha$ or $10 \mu \mathrm{M} \mathrm{D}-e-\mathrm{C}_{8}-$ Cer for various times. Ceramide bands were scraped from the silica gel plates and counted in a scintillation counter. (A) U937 cells treated with TNF- $\alpha$ for $60,120,180$ and $360 \mathrm{~min}$. Increase in endogenous ceramide is expressed as fold increase from control (untreated) cells. In control cells the ceramide concentration was approximately 50 pmoles per $1 \times 10^{6}$ cells. (B) Intracellular ceramide levels in U937 cells treated with $10 \mu \mathrm{M} \mathrm{D}-e-\mathrm{C}_{8}$-Cer for $2,7.5,15,30,60$ and $180 \mathrm{~min}$. (C) The autoradiogram of the TLC plate containing the ceramide bands that were scraped and counted in a scintillation counter shown in B. (D) Comparison of the ceramide levels in cells treated with $10 \mathrm{ng} / \mathrm{ml} \mathrm{TNF-} \alpha$ or $10 \mu \mathrm{M} \mathrm{D}-e-\mathrm{C}_{8}$-Cer. Concentration (in pmoles) is expressed as the difference from control. $\square$ pmoles of ceramide from cells treated with TNF- $\alpha$. $\diamond=$ pmoles of ceramide from cells treated with $\mathrm{D}-e-\mathrm{C}_{8}$-Cer 
quantitation $\left(50-2000\right.$ pmoles $\left.^{32}\right)$. Thus treatment of U937 cells with TNF- $\alpha$ induces a delayed and modest increase in the ceramide concentration, whereas exogenously added ceramide increases the intracellular ceramide concentration considerably and within $1 \mathrm{~min}$ of incubation (Figure 2D). Therefore, our data suggest that the differences in the killing time between ceramide and TNF- $\alpha$ could not be attributed to slow internalization and accumulation of ceramide within cells.

\section{Reversibility of D-e-C $\mathrm{C}_{8}$-Cer and TNF- $\alpha$ induced cell death in U937 cells}

Previous authors have shown TNF- $\alpha$ to induce a transitory increase in the endogenous level of ceramide ${ }^{4,15,29}$ and have speculated that the generation of ceramide leads to the activation of the cell death pathway. If the rise of endogenous ceramide is the mediator of the apoptotic signaling of TNF- $\alpha$, then transient exposure of cells to D-e-C 8 -Cer should increase the intracellular level of ceramide and trigger apoptosis.

Initially, we asked if exposure of cells to D-e-C $\mathrm{C}_{8}$-Cer for $3 \mathrm{~h}$, which increased the intracellular ceramide levels 18fold over the control (as indicated in Figure 2), was adequate to promote the commitment of U937 cells to the apoptotic pathway, U937 cells $\left(5 \times 10^{5} / \mathrm{ml}\right)$ were incubated with $10 \mu \mathrm{M} \mathrm{D}-e-\mathrm{C}_{8}-$ Cer for $3 \mathrm{~h}$ and then returned to ceramide-free media. The incubation was continued for a further $15 \mathrm{~h}$ (a total of $18 \mathrm{~h}$ ) and cell death was assessed by agarose gel electrophoresis. We did not detect nucleosomal fragmentation in cells treated with ceramide for $3 \mathrm{~h}$ and returned to ceramide-free media for $15 \mathrm{~h}$ more (Figure 3A). DNA fragmentation was detected only in cells constantly exposed to $10 \mu \mathrm{M}$ D-e-C 8 -Cer for $18 \mathrm{~h}$ (Figure $3 A)$. Furthermore, ceramide-induced cell death occurred only if cells were incubated in media that contained low concentrations of fetal bovine serum (1\% rather than $10 \%$, Figure $3 \mathrm{~A}$ ). Since serum is a source of growth factors the above data suggest that ceramide-induced cell killing is prevented by growth factors. The need for the constant presence of ceramide to kill cells was not restricted to cells treated with the $\mathrm{D}-e-\mathrm{C}_{8}$-Cer stereoisomer. U937 cells treated with the more potent stereoisomer $\mathrm{D}-\mathrm{t}-\mathrm{C}_{8}-\mathrm{Cer}^{11}$ for $3 \mathrm{~h}$ and then returned to ceramide-free media for $15 \mathrm{~h}$ more also did not die (Figure 3B). Apoptosis and nucleosomal fragmentation was only detected in cells continuously exposed to $\mathrm{D}-t-\mathrm{C}_{8}$-Cer (Figure $3 \mathrm{~B}$ ). Our results indicate that exposure of $U 937$ cells to $D-e-C_{8}-$ Cer or $D-t-C_{8}-$ Cer for a considerable amount of time $(3 \mathrm{~h}$, which as indicated in Figure 2 increases the intracellular level of ceramide 18-fold over control) was not enough to trigger cell death, and a continuous exposure to these compounds was necessary for cell killing. The reversibility of cell killing by ceramide was also seen in HL-60 cells (data not shown).

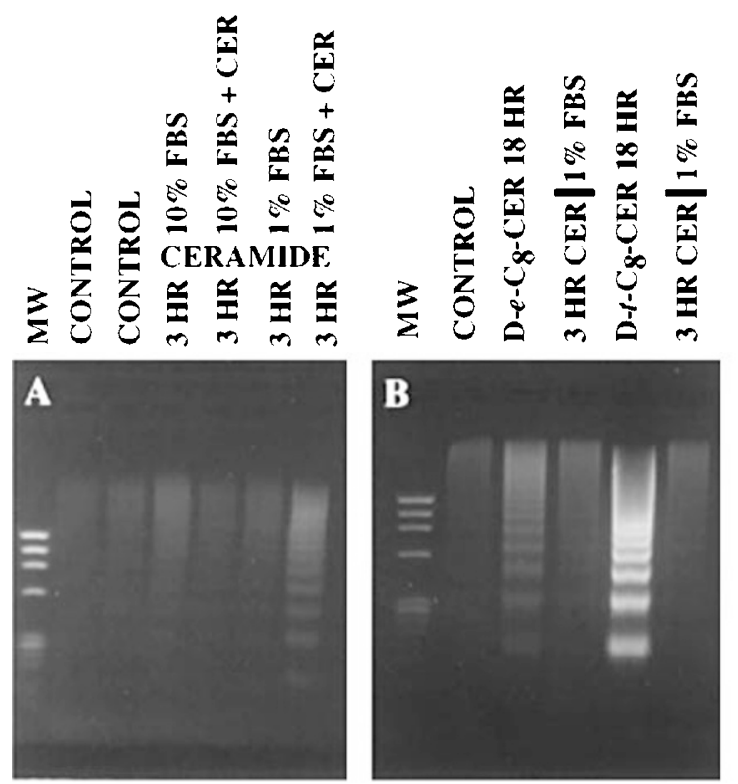

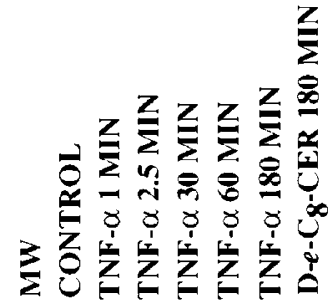
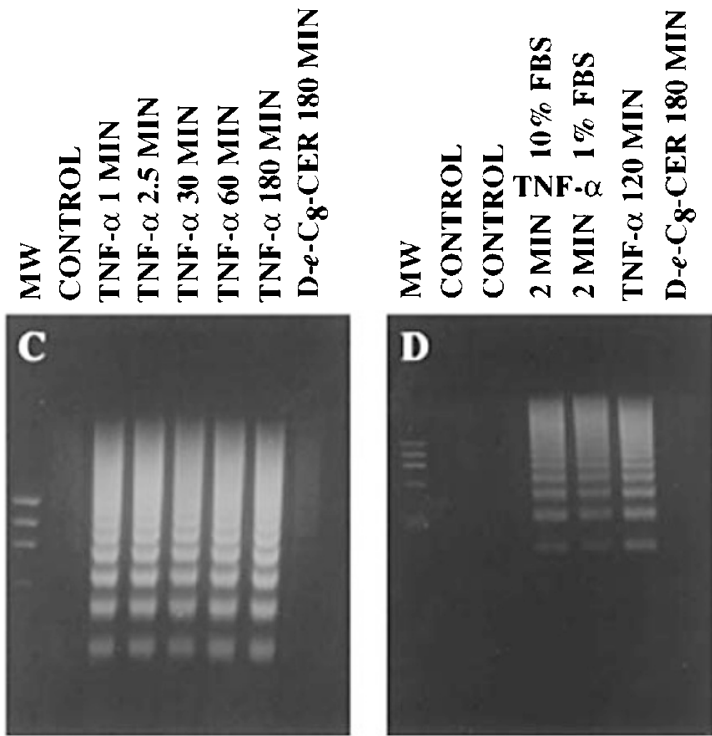

Figure 3 Agarose gel electrophoresis of DNA isolated from U937 cells transiently exposed to TNF- $\alpha$, D-e-C $-C_{8}-C_{1}$ or D- $t-C_{8}-C_{-}$. Agarose gel electrophoresis and

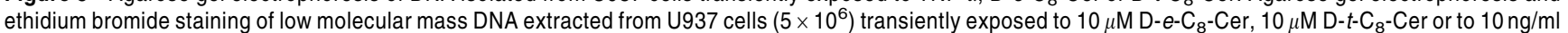
TNF- $\alpha$. (A) U937 cells were treated with $10 \mu \mathrm{M}$ D-e-C - -Cer for $3 \mathrm{~h}$, and returned to media containing 1 or $10 \%$ fetal bovine serum with or without $10 \mu \mathrm{M}$ D-e- $\mathrm{C}_{8}-\mathrm{Cer}_{\text {. }}$ The incubation was continued for another $15 \mathrm{~h}$ before the isolation of DNA. Cells treated with $0.1 \%$ ethanol for $3 \mathrm{~h}$ were returned to media containing 1 or $10 \%$ fetal bovine serum and used as controls (first 2 lanes, respectively). (B) U937 cells were treated with $10 \mu \mathrm{M} \mathrm{D}-e-\mathrm{C}_{8}-\mathrm{Cer}_{\text {or }} \mathrm{D}-\mathrm{t}-\mathrm{C}_{8}-\mathrm{Cer}_{\text {for }} 18 \mathrm{~h}$ or transiently exposed to $10 \mu \mathrm{M} \mathrm{D}-e-\mathrm{C}_{8}$-Cer or D- $t-\mathrm{C}_{8}$-Cer for $3 \mathrm{~h}$ and returned to media containing $1 \%$ fetal bovine serum. Cells transiently exposed to ceramide were further incubated for $15 \mathrm{~h}$ before the extraction of DNA. Control cells were exposed to $0.1 \%$ ethanol for $18 \mathrm{~h}$. (C) U937 cells treated with TNF- $\alpha$ for $1,2.5$, 30 and $60 \mathrm{~min}$ and returned to TNF- $\alpha$-free media for a total of $180 \mathrm{~min}$ before the isolation of DNA. The last two lanes contain DNA from cells treated with $10 \mathrm{ng} / \mathrm{ml}$ TNF- $\alpha$ or $10 \mu \mathrm{M}$ D-e-C $-\mathrm{Cer}$ for $180 \mathrm{~min}$, respectively. Cells incubated in media containing $1 \%$ fetal bovine serum for 180 min were used as controls. (D) DNA from U937 cells treated with TNF- $\alpha$ for 2 min and returned to TNF- $\alpha$-free media containing 10 or 1 min fetal bovine serum media for a total of 120 min. The last two lanes contain DNA from cells treated with TNF- $\alpha$ or D-e-C 8 -Cer for 120 min respectively. Cells treated with $0.1 \%$ ethanol for 2 min were returned to media containing 1 or $10 \%$ fetal bovine serum and used as controls (first 2 lanes, respectively). MW, molecular mass markers ( $\phi$ X174 DNA/HaellI) 
Treatment of cells with TNF- $\alpha$ produced a different result. U937 cells were treated for just $1 \mathrm{~min}$ with $10 \mathrm{ng} / \mathrm{ml}$ TNF- $\alpha$ and returned to TNF- $\alpha$-free media containing $1 \%$ fetal bovine serum. Cells were incubated in a TNF- $\alpha$-free media for a total of $2 \mathrm{~h}$ and apoptosis was assessed by DNA isolation and agarose gel electrophoresis. We detected DNA fragments in U937 cells treated for only $1 \mathrm{~min}$ with TNF- $\alpha$ (Figure 3C). The induction of cell death by TNF- $\alpha$ was unaffected by high concentrations of fetal bovine serum $(10 \%)$ in the media suggesting that an increase in the growth factor concentration does not prevent cell killing initiated by TNF- $\alpha$ (Figure 3D).

To determine what happens to accumulated ceramide once it is internalized, we exposed U937 cells to $10 \mu \mathrm{M} \mathrm{D}$ $e-C_{8}$-Cer for $3,6,12$ and $18 \mathrm{~h}$. At the end of the incubation the cells were either lysed for determination of the intracellular level of ceramide or returned to ceramide-free media. Cells returned to ceramide-free media were kept in the incubator for a total of $18 \mathrm{~h}$, lysed and the endogenous level of ceramide was determined. The endogenous levels of ceramide in cells treated with $\mathrm{D}-\mathrm{e}-\mathrm{C}_{8}$-Cer for $3,6,12$ and $18 \mathrm{~h}$ increased 18, 24, 30 and 22-fold above the control, respectively (Figure 4 , shaded bars). The endogenous levels of ceramide in cells treated with $\mathrm{D}-e-\mathrm{C}_{8}$-Cer for 3,6 and $12 \mathrm{~h}$ and then returned to ceramide-free media decreased to 2, 5 and 14-fold above the control, respectively (a crude estimate is that $t_{1 / 2}$ for the disappearance of ceramide is approximately $9 \mathrm{~h}$, indicating that ceramide is slowly degraded or modified into other sphingolipids, Figure 4, white bars). Thus, continuing the incubation of cells initially exposed to $D-e-C_{8}-C e r$ in ceramide-free media decreases the intracellular levels of ceramide reflecting the degradation or modification into other sphingolipids not phosphorylated by DG kinase within the cells. The decrease of ceramide (Figure 4, from 18-fold to twofold above the control) appears to be associated with the lack of nucleosomal DNA ladders (as indicated in the

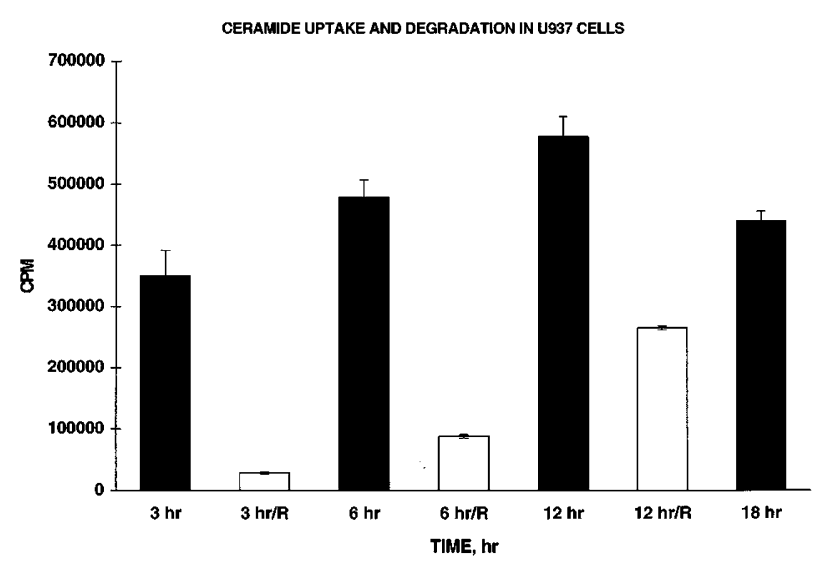

Figure 4 Internalization and degradation of ceramide in U937 cells treated with $\mathrm{D}-\mathrm{e}-\mathrm{C}_{8}$-Cer. Internalization and degradation of ceramide in U937 cells treated with $10 \mu \mathrm{M}$ D-e-C 8 -Cer for $3,6,12$ and $18 \mathrm{~h}$. Shaded bars, intracellular ceramide in cells treated with D-e-C - -Cer for $3,6,12$ and $18 \mathrm{hr}$. Open bars, intracellular ceramide in cells treated with $10 \mu \mathrm{M} \mathrm{D}-e-\mathrm{C}_{8}-$ Cer for 3,6 and $12 \mathrm{~h}$ and then returned to ceramide-free media containing $1 \%$ FCS for 15,12 and $6 \mathrm{~h}$, respectively previous experiment, Figure 3). These results suggest that U937 cells can tolerate considerable increases in ceramide for hours without activating the apoptotic pathway.

\section{Exogenous ceramide does not change the time required by TNF- $\alpha$ to induce apoptosis in U937 cells}

Although the above studies suggest that $\mathrm{D}-\mathrm{e}-\mathrm{C}_{8}-\mathrm{Cer}$ and TNF- $\alpha$ kill U937 cells with different kinetics, we detected a small increase of ceramide $1 \mathrm{~h}$ after treatment with TNF- $\alpha$ (Figure 2), and $30 \mathrm{~min}$ prior to the initiation of DNA fragmentation, (Figure 1). We therefore could not rule out the possibility that ceramide despite its late generation plays a role in TNF- $\alpha$ cell killing. To address whether ceramide is necessary for the initiation of the TNF- $\alpha$ cell killing or, as appears from our findings, a secondary factor, we increased the cellular levels of ceramide prior to the addition of TNF- $\alpha$. We assumed that if ceramide is critical in the initiation of apoptosis by TNF- $\alpha$, then providing U937 cells with ceramide prior to TNF- $\alpha$ exposure should decrease the time required for TNF- $\alpha$ cell killing.

U937 cells were either exposed to TNF- $\alpha$ alone, or pretreated with ceramide for $15 \mathrm{~min}$ (at which time ceramide levels increase to approximately twofold above the control, Figure 2B) and then exposed the cells to TNF- $\alpha$. DNA was collected from cells treated with TNF- $\alpha$ for $30,60,90$ and $120 \mathrm{~min}$ and apoptosis was assessed by DNA isolation and agarose gel electrophoresis. Pretreatment of cells with D-e$\mathrm{C}_{8}$-Cer for $15 \mathrm{~min}$ prior to the addition of TNF- $\alpha$ did not alter the time needed for TNF- $\alpha$ to kill cells (Figure 5). DNA fragmentation in cells treated with ceramide and TNF- $\alpha$ is detected after 90 and 120 min of incubation (Figure 5) and it is indistinguishable from DNA fragmentation in cells treated with TNF- $\alpha$ alone (Figure 5). DNA fragmentation was not detected in cells exposed to TNF- $\alpha$ alone or to both D-e-C $\mathrm{B}^{-}$ Cer and TNF- $\alpha$ for 30 and $60 \mathrm{~min}$ (Figure 5). Thus the increase of intracellular ceramide level prior to the addition of $\mathrm{TNF}-\alpha$ did not change the time required by TNF- $\alpha$ to induce DNA fragmentation in $U 937$ cells. A minimum of $90 \mathrm{~min}$ incubation was needed for the induction of cell death by TNF$\alpha$. Therefore, our results suggest that ceramide elevations are likely to be a consequence rather than a cause of TNF- $\alpha$ cell killing.

\section{Low $\mathrm{pH}$ washes and trypsinization do not inhibit cell death promoted by exposure to TNF- $\alpha$}

Exposure of U937 cells to $10 \mathrm{ng} / \mathrm{ml}(0.57 \mathrm{nM})$ of TNF- $\alpha$ for just $1 \mathrm{~min}$ was sufficient to induce cell death (Figure $3 \mathrm{C}$ ). In addition, TNF- $\alpha$ killed cells at very low concentrations suggesting that TNF- $\alpha$-sensitive cells could be eliminated at physiologically relevant concentrations of TNF- $\alpha$ (Figure $6 \mathrm{~A})$. Based on these results, we speculated that the apoptotic signaling initiated by TNF- $\alpha$ was an early and irreversible event requiring low concentrations of TNF- $\alpha$. However, we could not exclude the possibility that complexes formed between TNF- $\alpha$ and its receptor remained intact after the washing with $\mathrm{NaCl} / \mathrm{P}_{\mathrm{i}}$. In that case, bound TNF- $\alpha$ could continue signaling suggesting that 


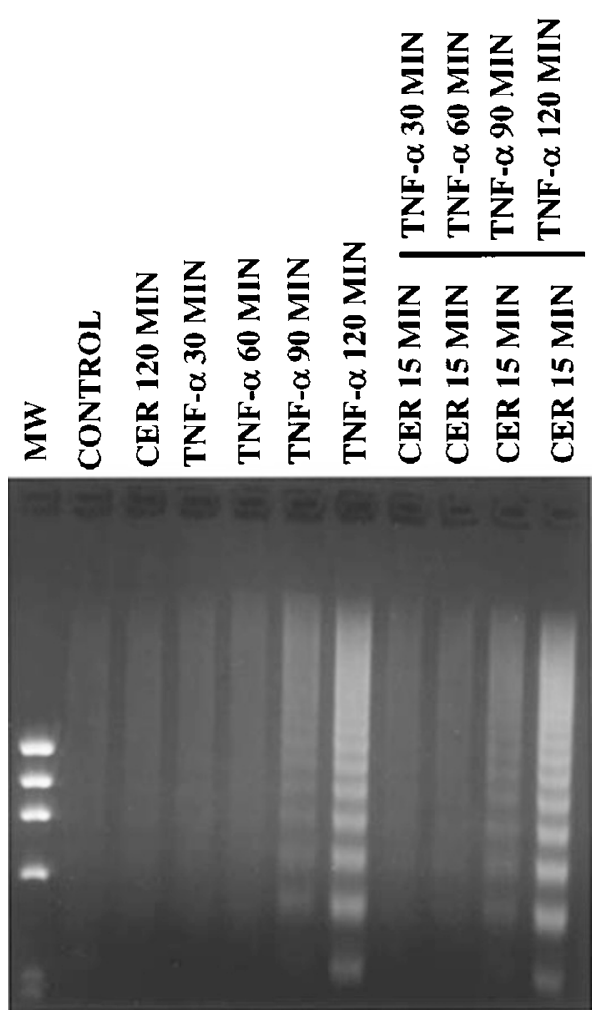

Figure 5 Internalization of exogenous ceramide does not change the time required by TNF- $\alpha$ to kill cells. Agarose gel electrophoresis and ethidium bromide staining of low molecular mass DNA isolated from U937 cells $\left(5 \times 10^{6}\right)$ treated with $10 \mathrm{ng} / \mathrm{ml} \mathrm{TNF-} \alpha$ or pre-exposed to $10 \mu \mathrm{M} \mathrm{D}-e-\mathrm{C}_{8}-\mathrm{Cer}$ for $15 \mathrm{~min}$ before the addition of $10 \mathrm{ng} / \mathrm{ml}$ TNF- $\alpha$. DNA was collected $30,60,90$ and $120 \mathrm{~min}$ after the addition of TNF- $\alpha$. Untreated cells or cells treated with $10 \mu \mathrm{M}$ $\mathrm{D}-\mathrm{e}-\mathrm{C}_{8}$-Cer for $2 \mathrm{~h}$ were used as controls. MW, DNA molecular mass standards ( $\phi$ X174 DNA/HaellI)

the apoptotic signals may arise well after the initial receptorligand interactions. Other investigators have disrupted receptor-ligand signaling by washing cells in low $\mathrm{pH}$ buffers or by receptor proteolysis. ${ }^{33,34}$ Similarly, we exposed U937 cells to very low concentrations of TNF- $\alpha$ so that only a small fraction of the TNF- $\alpha$ receptors is occupied, followed by acid washes or trypsinization. We assumed that dissociation of the ligand-receptor complexes by acid washes and proteolytic cleavage of the TNF receptors could interrupt the apoptotic signaling cascade of TNF- $\alpha$ and prevent cell death. Previous studies with U937 cells showed that a minimum of $10 \mathrm{pM}$ TNF- $\alpha$ (a $17 \%$ TNF receptor occupancy) was necessary to translocate NF- $\kappa$ B in U937 cells. ${ }^{34}$ The $\mathrm{K}_{\mathrm{D}}$ (concentration that gives half-maximal binding) for U937 cells was shown to be $22 \mathrm{pM}^{35}$

We initially tested if transient exposure of U937 cells to a very low concentration of TNF- $\alpha$ was adequate to promote cell death. U937 cells were treated with $0.01 \mathrm{ng} / \mathrm{ml}$ of TNF- $\alpha$ for 2 min. Even at this low concentration of TNF- $\alpha$, we detected DNA fragmentation (Figure 6). The induction of cell death by such low concentrations of TNF- $\alpha$ suggest that the cell death signaling transduced by the TNF receptor is transmitted with a very small percentage of receptor occupancy.

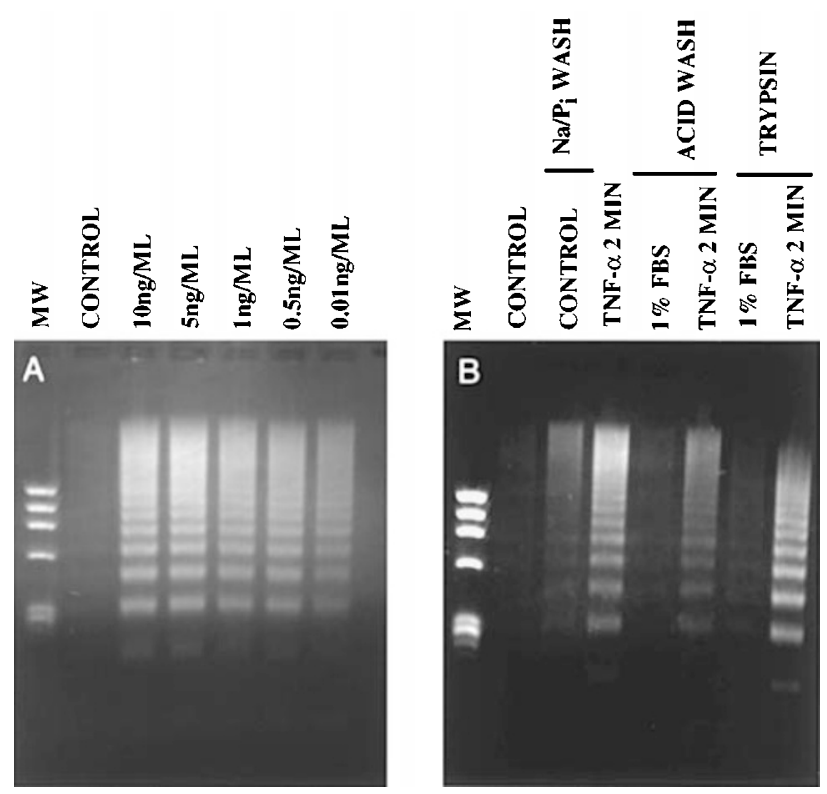

Figure 6 TNF- $\alpha$ dose response, acid wash and trypsinization of U937 cells exposed to TNF- $\alpha$ (A) Agarose gel electrophoresis and ethidium bromide staining of low molecular mass DNA isolated from $5 \times 10^{6}$ cells treated with $10-0.01 \mathrm{ng} / \mathrm{ml}$ TNF- $\alpha$ for $2 \mathrm{~h}$. Control cells were incubated in the absence of TNF- $\alpha$. (B) Agarose gel electrophoresis and ethidium bromide staining of low molecular mass DNA isolated from cells treated with $0.01 \mathrm{ng} / \mathrm{ml} \mathrm{TNF-} \alpha$ for 2 min and washed in either $\mathrm{NaCl} / \mathrm{P}_{i} \mathrm{pH} 7.4$ or $\mathrm{NaCl} / \mathrm{P}_{i} \mathrm{pH} 3.0$ (acid wash) or treated with $100 \mu \mathrm{g} / \mathrm{ml}$ trypsin. Cells were returned to TNF-free media containing $1 \%$ fetal bovine serum for a total of $2 \mathrm{~h}$ before the extraction of DNA. MW, DNA molecular mass standards ( $\phi$ X174 DNA/HaellI)

To show that the cell death signaling transduced by TNF$\alpha$ is mediated within the first $\min$ of the exposure, we investigated if acid washes and trypsinization, which disrupt the receptor-ligand signaling, could inhibit cell death transduced by TNF- $\alpha$. Acid washing was performed as described previously ${ }^{33}$ and described in the Materials and Methods. As shown in Figure 6B, washing of cells in acidic conditions did not inhibit apoptosis transduced by low concentrations of TNF $-\alpha(0.01 \mathrm{ng} / \mathrm{ml})$. Similarly, incubation of U937 cells with $0.01 \mathrm{ng} / \mathrm{ml}$ of TNF- $\alpha$ for 2 min followed by trypsinization $(100 \mu \mathrm{g} / \mathrm{ml}$ in serum-free media), did not prevent cells from dying (Figure 6B). Therefore, acid washing and trypsinization did not inhibit apoptosis mediated by TNF- $\alpha$. The inability to prevent cell death, by disrupting the receptor-ligand complexes, by acid washes and trypsinization strongly suggests that TNF- $\alpha$ treated cells (unlike ceramide treated cells) commit themselves to the apoptotic pathway within seconds of exposure to TNF- $\alpha$.

\section{Discussion}

Apoptosis triggered by TNF- $\alpha,{ }^{15,22}$ Fas antigen, ${ }^{23,36}$ ionizing radiation, ultraviolet radiation, and heat shock ${ }^{18}$ is hypothesized to be mediated by the second messenger ceramide. The data from these studies suggest that the intracellular ceramide accumulation is associated with the receptor-ligand complex formation and the activation of the apoptotic signaling. ${ }^{37,38}$ Although there is little controversy over the 
generation of ceramide under conditions that lead to cell death, the requirement of ceramide for the activation of the apoptotic pathway is speculative.

In the current study we investigated mechanisms by which ceramide and TNF- $\alpha$ kill U937 cells. U937 cells were used extensively for the elucidation of the cell death signaling of TNF- $\alpha$ and ceramide. ${ }^{15,22,31}$ Our study attempts to extend these initial observations and clarify the role of ceramide in the cell death signaling of TNF- $\alpha$ in a system that has been previously established. We hypothesized that if ceramide is the mediator of cell death by TNF- $\alpha$, then exogenously added ceramide and TNF- $\alpha$ should require similar exposure times to kill cells. In addition, we assumed that a direct relationship between ceramide elevation and the commitment to cell death should have been present in ceramide and TNF- $\alpha$ treated cells. This was not the case (Figures 1 and 2). U937 cells started to die within $90 \mathrm{~min}$ of exposure to TNF- $\alpha$, whereas ceramide required at least $12 \mathrm{~h}$ to kill. The difference in cell killing was not attributed to the slow internalization of the exogenously added ceramide (Figure 2). Short chain ceramides were shown previously to saturate cellular membranes quickly ${ }^{39}$ and activate ceramide targets within $1 \mathrm{~min} .{ }^{40-42}$ For instance, 10 min exposure of A431 cells to $10 \mu \mathrm{M} \mathrm{C}_{8}$-Cer was adequate to induce maximal phosphorylation of the epidermal growth factor receptor. ${ }^{41}$ Thus, rapid and massive increases in intracellular ceramide were not adequate to cause early cell killing or commit cells to the apoptotic pathway (Figures 1-3).

In contrast, TNF- $\alpha$ killed U937 cells rapidly, within $90 \mathrm{~min}$ of exposure, with late and modest elevations of endogenous ceramide (Figures 1 and 2). Thus ceramide and TNF- $\alpha$ kill cells with different kinetics and this difference in cell killing is not governed by intracellular ceramide elevations. These observations strongly suggest that exogenously added ceramide and TNF- $\alpha$ kill cells via different pathways.

Previous studies with the U937 variant cell line U9-TR indicated that the resistance of cell killing by TNF- $\alpha$ was associated with the lack of ceramide generation. ${ }^{31}$ Furthermore, addition of exogenous ceramide induced apoptosis in U9-TR cells suggesting that the block in TNF- $\alpha$ cytotoxicity was probably due to the failure to hydrolyze sphingomyelin and generate ceramide. However, these observations are suggestive because concrete evidence for the involvement of ceramide as the mediator of the apoptotic signaling of $T N F-\alpha$ is lacking. If indeed ceramide and TNF- $\alpha$ kill cells via a different pathway, then addition of exogenous ceramide will kill cells irrespectively of whether there is a block in the apoptotic signaling of TNF- $\alpha$.

The ability of TNF- $\alpha$ to activate apoptosis at low concentrations $(0.01 \mathrm{ng} / \mathrm{ml})$ and within the first $2 \mathrm{~min}$ of treatment, even when cells were acid-washed or exposed to trypsin (Figure 6) suggests that cell death induced by TNF- $\alpha$ is (a) transduced rapidly and within minutes of exposure to TNF- $\alpha$, (b) irreversible and (c) effectuated by a very low receptor occupancy. The ability of TNF- $\alpha$ to transduce signals rapidly and at low concentrations is not restricted to the activation of apoptosis. Similarly, picomolar concentrations of TNF- $\alpha$ were shown to translocate NF- $\kappa \mathrm{B}$ within a few minutes. ${ }^{34,43,44}$ It is therefore likely that the apoptotic signaling cascade mediated by TNF- $\alpha$ is transduced with the same rapidity as the signaling that translocates NF- $\kappa \mathrm{B}$. More importantly, ceramide generation in $U 937$ cells begins $1 \mathrm{~h}$ post-treatment with TNF- $\alpha$ and well after the $2 \mathrm{~min}$ needed by cells to commit themselves to the apoptotic pathway indicating that ceramide generation is not required for the activation of cell death. Another line of evidence supporting that ceramide may not mediate the apoptotic signaling of TNF- $\alpha$ is that the provision of D-e$\mathrm{C}_{8}$-Cer prior to the hydrolysis of the sphingomyelin pools by TNF- $\alpha$ did not alter the timing needed by TNF- $\alpha$ to kill cells (Figure 5). Under these conditions, the availability of ceramide did not change the kinetics of cell killing initiated by TNF- $\alpha$.

Contrary to TNF- $\alpha, D-e-C_{8}-$ Cer and D- $t-C_{8}-$ Cer failed to activate apoptosis even under prolonged incubations $(3 \mathrm{~h}$, Figure $3 \mathrm{~A}$ and $\mathrm{B})$. Continuous incubation with $\mathrm{D}-\mathrm{e}-\mathrm{C}_{8}-\mathrm{Cer}$ or $\mathrm{D}-\mathrm{t}-\mathrm{C}_{8}$-Cer in media containing low fetal bovine serum concentrations $(1 \%)$ was essential for the detection of DNA fragmentation ladders (Figure $3 A$ and $B$ ). The intracellular ceramide levels in cells treated with $\mathrm{D}-\mathrm{e}-\mathrm{C}_{8}-\mathrm{Cer}$ surpassed significantly the ceramide levels generated by TNF- $\alpha$ (Figure 2), without activating apoptosis (Figures 1 and 2). It is therefore possible that unlike TNF- $\alpha$, cell death induced by $\mathrm{D}-\mathrm{e}-\mathrm{C}_{8}$-Cer and the other ceramide stereoisomers to arises from toxic effects due to the sustained accumulation of unphysiologically high concentrations of ceramide within cells and the prolonged activation of ceramide targets such as the CAPK and CAPP (shown to be maximally activated by $10 \mu \mathrm{M}$ ceramide). ${ }^{40,42}$ The use of ceramide concentrations exceeding $10 \mu \mathrm{M}(25-100 \mu \mathrm{M})^{10,18,45}$ may test the cell tolerance to unphysiologically high ceramide concentrations, but may not necessarily clarify the importance of ceramide in the cell death signaling initiated by TNF- $\alpha$. The ceramide concentration generated by TNF- $\alpha$ is significantly less than the intracellular concentration of ceramide in cells treated with $\mathrm{D}-e-\mathrm{C}_{8}$-Cer (Figure 2).

Several studies indicated that sphingomyelin pools are found in different subcellular compartments and their selective hydrolysis has been associated with different cellular responses. ${ }^{4,46,47}$ Interestingly, the location of the sphingomyelin pool hydrolyzed by TNF- $\alpha$ is controversial. Several investigators have proposed that the TNF- $\alpha$ sensitive pool resides in the external leaflet of the plasma membrane. ${ }^{48}$ Others proposed that the sphingomyelin pool hydrolyzed by TNF- $\alpha$ is localized in the endolysosomal compartments ${ }^{4}$ or the inner leaflet of the plasma membrane. ${ }^{47,49}$ One could argue that exogenous ceramide kills cells with different kinetics, because of its differential accumulation in subcellular compartments that are different from those generated by TNF- $\alpha$. Studies with synthetic fluorescent ceramide analogs have shown ceramide to accumulate in the Golgi apparatus and sequentially in other membrane compartments ${ }^{39}$ suggesting that cellular membranes are saturated quickly in the presence of exogenous ceramide. Ethanol has been used extensively as the delivery system for ceramide ${ }^{11,12,15,22}$ and there is no evidence that different ceramide delivery vehicles can target ceramide to particular subcellular compartments. If 
TNF- $\alpha$ and other stress signals generate ceramide in subcellular compartments that are inaccessible to exogenously added ceramide, then the use of exogenous ceramides to study the cell death mechanisms of TNF- $\alpha$ and other factors that lead to cell death may be irrelevant.

Recent studies revealed that TNF- $\alpha$-receptor complex recruits the cytoplasmic factors FADD and TRADD that may assist in the propagation of the cell death signaling to the apoptotic apparatus. ${ }^{50}$ The ability of exogenous ceramide to activate or recruit these factors in a way similar to TNF- $\alpha$ has not been confirmed. It is therefore possible that the differences in cell killing between TNF- $\alpha$ and exogenous ceramide to arise from the inability of exogenous ceramide to assemble the apoptotic apparatus in a manner similar to TNF- $\alpha$. Although this is an existing possibility requiring further investigation, our data strongly indicates that exogenous ceramide alone is not adequate to promote apoptosis in U937 cells with the same kinetics as TNF- $\alpha$.

Another important consideration is that ceramide generation has not been exclusively associated with apoptosis. Ceramide was shown to stimulate cellular proliferation in fibroblasts. ${ }^{8}$ In other studies, the generation of ceramide by interleukin-1 $\beta$ in dendrocytes was not associated with apoptosis, although exogenously added ceramide killed dendrocytes. ${ }^{51}$ Furthermore, ceramide was not found to be an upstream messenger in the cell death signaling mediated by Fas. In these studies, ceramide generation was regarded as a consequence rather than a cause of apoptosis. ${ }^{52}$ All these observations suggest that the cellular generation of ceramide may not necessarily lead to cell death and that ceramide may be the consequence rather than the cause of apoptosis.

\section{Materials and Methods}

\section{Materials}

RPMI, penicillin, streptomycin, fetal bovine serum, and L-glutamine were obtained from Biofluids, Inc. $\left[\gamma^{32} \mathrm{P}\right] \mathrm{dATP}(3000 \mathrm{Ci} / \mathrm{mmol})$ were from Amersham Corp. Diethylenetriamine-pentaacetic acid, natural ceramide (type III from bovine brain) and Hoechst 33258 stain were purchased from Sigma. Cardiolipin (beef heart) was from Avanti Polar Lipids. $N$-Octyl- $\beta$-D-glucopyranoside and Escherichia coli diacylglycerol (DG) kinase were from Calbiochem. DNA molecular mass markers ( $\phi \times 174$ DNA/Haell fragments) were from Gibco BRL. TLC plates ( $6 \mathrm{~nm}$ silica gel plates of $0.25 \mathrm{~mm}$ thickness) were from Whatman. $\mathrm{N}$-octanoyl-D-erythro-sphingosine (D-e-C $\mathrm{C}_{8}$-Cer) was purchased from Biomol. N-octanoyl-D-threo-sphingosine (D-t- $\mathrm{C}_{8}-\mathrm{Cer}$ ) was kindly provided by Dr. Robert Bittman, Queens College. TNF- $\alpha$ was from R\&D systems. RNase A was purchased from Boehringer and Mannheim. Trypsin was from Gibco BRL. U937 cells (human histiocytic lymphoma) were purchased from American Type Culture Collection (ATCC).

\section{Staining of U937 cells with bis-benzimide}

To assess the degree of apoptosis in ceramide and TNF- $\alpha$-treated cells, we stained U937 cells with the DNA fluorochrome bis-benzimide (Hoechst 33258) as described previously. ${ }^{11}$ Briefly, at the end of the incubation with ceramide or TNF- $\alpha$, the cells were washed with $\mathrm{NaCl} / \mathrm{P}_{\mathrm{i}}$ and fixed in $3 \%$ paraformaldehyde. Subsequently, the cells were washed in $\mathrm{NaCl} / \mathrm{P}_{\mathrm{i}}$ and the nuclei were stained with $16 \mu \mathrm{g} / \mathrm{ml}$ bisbenzimide. Nuclei with supercondensed chromatin at the nuclear periphery or nuclei fragmented into smaller dense bodies were considered apoptotic. Nuclei with evenly dispersed chromatin were considered as not apoptotic.

\section{Tissue culture cells and treatment}

U937 cells were maintained in RPMI 1640 supplemented with $10 \%$ fetal bovine serum, $2 \mathrm{mM} \mathrm{L}$-glutamine, $50 \mathrm{U} / \mathrm{ml}$ penicillin and $100 \mu \mathrm{g} /$ $\mathrm{ml}$ streptomycin. The cultures were maintained under a humidified atmosphere of $95 \%$ air and $5 \% \mathrm{CO}_{2}$ at $37^{\circ} \mathrm{C}$. Before treatment, U937 cells were washed once in phosphate-buffered saline $\left(\mathrm{NaCl} / \mathrm{P}_{\mathrm{i}}\right.$, $137 \mathrm{mM} \mathrm{NaCl}, 2.7 \mathrm{mM} \mathrm{KCl}, 4.3 \mathrm{mM} \mathrm{Na} 2 \mathrm{HPO}_{4} \cdot 7 \mathrm{H}_{2} \mathrm{O}, 1.4 \mathrm{mM}$ $\left.\mathrm{KH}_{2} \mathrm{PO}_{4}, \mathrm{pH} 7.4\right)$ and then resuspended $\left(5 \times 10^{5}\right.$ cells/ml) in RPMl containing $1 \%$ fetal bovine serum, antibiotics and glutamine. D-e- $\mathrm{C}_{8}-$ Cer was dissolved in ethanol and added to the cells as ethanolic solution (final concentration of ethanol not exceeding $0.1 \%$ ). Lyophilized TNF- $\alpha$ was reconstituted in $0.1 \%$ bovine serum albumin $(10 \mathrm{ng} / \mu \mathrm{l})$. Cells were incubated in the presence of $10 \mu \mathrm{M} \mathrm{D}-\mathrm{e}-\mathrm{C}_{8}-\mathrm{Cer}$ or different concentrations of TNF- $\alpha$ for specified times. At the end of the incubation, cells were pelleted, washed once with $\mathrm{NaCl} / \mathrm{P}_{\mathrm{i}}, \mathrm{pH} 7.4$ and lysed for low molecular mass DNA isolation.

For the studies testing the reversibility of induction of cell death induction, U937 cells were plated in RPMI media containing $1 \%$ fetal bovine serum, antibiotics and glutamine. Cells treated with $10 \mu \mathrm{M} \mathrm{D}-e-$ $\mathrm{C}_{8}$-Cer for $3 \mathrm{~h}$ were transferred into fresh media containing $10 \%$ or $1 \%$ fetal bovine serum with or without $10 \mu \mathrm{M} \mathrm{D}-e-\mathrm{C}_{8}$-Cer. The cells were incubated for an additional $15 \mathrm{~h}$ (total incubation $18 \mathrm{~h}$ ), washed once with $\mathrm{NaCl} / \mathrm{P}_{\mathrm{i}}, \mathrm{pH} 7.4$ and lysed for DNA isolation.

For the studies testing the reversibility of induction of cell death with TNF- $\alpha$, U937 cells were treated with the indicated concentrations of TNF- $\alpha$ for various times, washed once with $\mathrm{NaCl} / \mathrm{P}_{\mathrm{i}}, \mathrm{pH} 7.4$ and returned to TNF- $\alpha$-free media (RPMI) supplemented with $10 \%$ or $1 \%$ fetal bovine serum. The incubation was continued for a total of $2 \mathrm{~h}$ and the low molecular mass DNA was extracted and electrophoresed as above to assess DNA fragmentation. All experimental procedures were repeated at least three times.

\section{DNA isolation}

U937 cells $\left(5 \times 10^{6}\right)$ were lysed in $600 \mu$ cell lysis buffer $(10 \mathrm{mM}$ Tris$\mathrm{HCl}, 0.2 \%$ Triton $\mathrm{X}-100$ and $10 \mathrm{mM}$ EDTA, pH 7.5). The cell lysate was incubated on ice for $10 \mathrm{~min}$ and then centrifuged at $4^{\circ} \mathrm{C}$ at $12000 \times \mathrm{g}$ for $15 \mathrm{~min}$. The supernatant, containing the low molecular mass DNA was incubated for $1 \mathrm{~h}$ with $100 \mu \mathrm{g} / \mathrm{ml}$ RNase A and then extracted twice with $600 \mu \mathrm{l}$ of phenol:chloroform:isoamyl alcohol $(24: 24: 1)$ and once with $600 \mu \mathrm{l}$ of chloroform:isoamyl alcohol $(24: 1)$. The DNA was precipitated with $300 \mathrm{mM} \mathrm{NaCl}$ and 2.5 volumes ethanol at $-20^{\circ} \mathrm{C}$ overnight. The next day the samples were centrifuged at $16000 \times g$ for $30 \mathrm{~min}$ and the DNA pellet was washed once with $75 \%$ ethanol, air dried, and suspended in $20 \mu \mathrm{l}$ of $10 \mathrm{mM}$ Tris- $\mathrm{HCl}, 1 \mathrm{mM}$ EDTA, pH 8.0 (T.E.). The degree of DNA fragmentation was analyzed by agarose gel electrophoresis as described previously. ${ }^{11}$

\section{Ceramide labeling and quantitation by diacylglycerol (DG) kinase}

The intracellular level of ceramide was determined by the $E$. coli DG kinase assay ${ }^{53}$ as described previously. ${ }^{11}$ Briefly, U937 cells were washed with $\mathrm{NaCl} / \mathrm{P}_{\mathrm{i}}, \mathrm{pH} 7.4$ and plated at a concentration of $5 \times 10^{5}$ cells $/ \mathrm{ml}$ in media containing $1 \%$ fetal bovine serum. After treatment 
with ceramide or TNF- $\alpha$, the cells were washed once with $\mathrm{NaCl} / \mathrm{P}_{\mathrm{i}}$, $\mathrm{pH} 7.4$ and lysed in $1 \mathrm{ml}$ chloroform/methanol/1 $\mathrm{N} \mathrm{HCl}(100 / 100 / 1, \mathrm{v} / \mathrm{v} /$ v). The organic phase was separated with the addition of $270 \mu \mathrm{l}$ of buffered saline solution (BSS, $135 \mathrm{mM} \mathrm{NaCl}, 4.5 \mathrm{mM} \mathrm{KCl}, 1.5 \mathrm{mM}$ $\mathrm{CaCl}_{2}, 0.5 \mathrm{mM} \mathrm{MgCl}_{2}, 5.6 \mathrm{mM}$ glucose and $10 \mathrm{mM} \mathrm{HEPES}, \mathrm{pH} 7.2$ ), and $30 \mu \mathrm{l}$ of $100 \mathrm{mM}$ EDTA. The lower organic phase was dried under a stream of $\mathrm{N}_{2}$.

To destroy glycerophospholipids, the extracted total lipids were subjected to mild alkaline hydrolysis $(0.1 \mathrm{M}$ methanolic potassium hydroxide for $1 \mathrm{~h}$ at $37^{\circ} \mathrm{C}$ ). The organic phase was isolated and dried under $\mathrm{N}_{2}$. Cellular lipids were solubilized by bath sonication and labeled by DG kinase as described previously. ${ }^{11}$ Each TLC lane contained ceramide extracted from $3 \times 10^{6}$ cells. The TLC plates were subjected to autoradiography for 6-24 h, depending on the intensity of the labeled ceramide bands, and the silica from the TLC plates containing the ceramide was scraped and quantitated by liquidscintillation counting. Ceramide type III was labeled the same way as lipids extracted from cells and used as standard.

\section{Determination of the fate of internalized

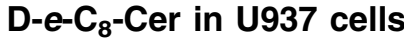

To determine the fate of ceramide internalized by U937 cells, two separate flasks of cells $\left(6 \times 10^{6}\right.$ cells/flask $)$ were exposed to $10 \mu \mathrm{M} \mathrm{D}$ $e-C_{8}$-Cer. The cells were incubated in the presence of ceramide for different times. At the end of the incubation period the cells from one of the two flasks were washed once with $\mathrm{NaCl} / \mathrm{P}_{\mathrm{i}}, \mathrm{pH} 7.4$, lysed, and the lipids were collected for the assessment of the intracellular level of ceramide. The cells of the second flask were centrifuged, returned to ceramide-free media containing $1 \%$ fetal bovine serum and allowed to incubate for a total of up to $18 \mathrm{~h}$. At the end of this incubation, the cells were washed with $\mathrm{NaCl} / \mathrm{P}_{\mathrm{i}}, \mathrm{pH} 7.4$ and lysed. The intracellular level of ceramide was ascertained as described above.

\section{Acid wash and trypsinization of TNF- $\alpha$ treated cells}

To interrupt the propagation of the signals transduced by the TNF receptors we washed U937 cells in low $\mathrm{pH} \mathrm{NaCl} / \mathrm{P}_{\mathrm{i}}(\mathrm{pH} 3.0)$ or proteolytically cleaved the TNF receptors with trypsin. $\mathrm{Low} \mathrm{pH} \mathrm{NaCl} / \mathrm{P}_{\mathrm{i}}$ (pH 3.0) washes, which disrupt receptor-ligand associations and stop the receptor signaling, were done as described previously. ${ }^{33}$ Briefly, $5 \times 10^{6}$ U937 cells were exposed to $0.57 \mathrm{pM}$ of TNF- $\alpha(0.01 \mathrm{ng} / \mathrm{ml})$ for $2 \mathrm{~min}$, and washed once with ice cold $\mathrm{NaCl} / \mathrm{P}_{\mathrm{i}}, \mathrm{pH} 7.4$ and then the cell pellet was resuspended in $2 \mathrm{ml}$ of ice cold $\mathrm{NaCl} / \mathrm{P}_{\mathrm{i}}, \mathrm{pH} 3$ for 2 min on ice. The cells were washed with $\mathrm{NaCl} / \mathrm{P}_{\mathrm{i}}, \mathrm{pH} 7.4$ and returned to TNF- $\alpha$ free media containing $1 \%$ fetal bovine serum. The incubation was continued for a total of $2 \mathrm{~h}$. Control cells were carried through the same procedure, but without TNF- $\alpha$ treatment. Low molecular mass DNA was extracted to assess the degree of apoptosis.

Another means of interrupting the TNF receptor signaling is by proteolytic cleavage of the receptors with proteases, such as trypsin. Trypsinization was performed as described previously. ${ }^{34}$ U937 cells $\left(5 \times 10^{6}\right)$ were exposed to $0.57 \mathrm{pM}$ of TNF- $\alpha$ for $2 \mathrm{~min}$ and then washed in ice cold $\mathrm{NaCl} / \mathrm{P}_{\mathrm{i}}, \mathrm{pH}$ 7.4. The cell pellet was suspended in $10 \mathrm{ml}$ of fetal bovine serum-free media containing $100 \mu \mathrm{g} / \mathrm{ml}$ trypsin. The cells were further incubated for a total of $2 \mathrm{~h}$. Cells not exposed to TNF- $\alpha$ were treated in a similar manner and used as controls.

\section{Acknowledgements}

We would like to thank Dr. Richard Lockshin for the critical reading of this manuscript. This work was supported by the National Institute of Aging
Grant- KO4 -AG0031 (to Z.Z.), and the Alzheimer's Association/AlliedSignal Foundation Pilot Research grant (to Z.Z.).

\section{References}

1. Okazaki T, Bielawska A and Hannun YA (1989) Sphingomyelin turnover induced by vitamin $D_{3}$ in HL-60 cells. J. Biol. Chem. 264: $19076-19080$

2. Okazaki T, Bielawska A, Domae N, Bell RM and Hannun YA (1994) Characteristics and partial purification of a novel cytosolic, magnesiumindependent, neutral sphingomyelinase activated in the early signal transduction of 1 alpha,25-dihydroxyvitamin $\mathrm{D}_{3}$-induced $\mathrm{HL}-60$ cell differentiation. J. Biol. Chem. 269: 4070-4077

3. Okazaki T, Bielawska A, Bell RM and Hannun YA (1990) Role of ceramide as a lipid mediator of 1 alpha,25-dihydroxyvitamin $\mathrm{D}_{3}$-induced $\mathrm{HL}-60$ cell differentiation. J. Biol. Chem. 265: 15823-15831

4. Wiegmann K, Schutze S, Machleidt T, Witte D and Kronke M (1994) Functional dichotomy of neutral and acidic sphingomyelinases in tumor necrosis factor signaling. Cell 78: 1005-1015

5. Heller RA and Kronke M (1994) Tumor necrosis factor receptor-mediated signaling pathways. J. Cell. Biol. 126: 5-9

6. Santana P, Peña LA, Friedman A-H, Martin S, Green D, McLoughlin M, Cardo CC, Schuchman ED, Fuks Z and Kolesnick R (1996) Acid sphingomyelinasedeficient human lymphoblasts and mice are defective in radiation-induced apoptosis. Cell 86: $189-199$

7. Ito A and Horigome K (1995) Ceramide prevents neuronal programmed cell death induced by nerve growth factor deprivation. J. Neurochem. 65: 463-466

8. Olivera A, Buckley E and Spiegel S (1992) Sphingomyelinase and cellpermeable ceramide analogs stimulate cellular proliferation in quiescent swiss 3T3 fibroblasts. J. Biol. Chem. 267: 26121-26127

9. Dbaibo G, Pushkareva MY, Jayadev S, Schwarz JK, Horowitz JM, Obeid LM and Hannun YA (1995) Retinoblastoma gene product as a downstream target for a ceramide-dependent pathway of growth arrest. Proc. Natl. Acad. Sci. USA 92: $1347-1351$

10. Jayadev S, Liu B, Bielawska AE, Lee JY, Nazaire F, Pushkareva MY, Obeid LM and Hannun YA (1995) Role of ceramide in cell cycle arrest. J. Biol. Chem. 270: 2047-2052

11. Karasavvas N, Erukulla RK, Bittman R, Lockshin R and Zakeri Z (1996a) Stereospecific induction of apoptosis in U937 cells by $\mathrm{N}$-octanoyl-sphingosine stereoisomers and the novel ceramide analog $\mathrm{N}$-octyl-sphingosine. Eur. J. Biochem. 236: 729-737

12. Karasavvas N, Erukulla RK, Bittman R, Lockshin R, Hockenbery D and Zakeri Z (1996b) Bcl-2 suppresses ceramide-induced cell killing. Cell Death Differ. 3: $149-151$

13. Rivas Cl, Golde DW, Vera JC and Kolesnick RN (1994) Involvement of the sphingomyelin pathway in autocrine tumor necrosis factor signaling for human immunodeficiency virus production in chronically infected HL-60 cells. Blood 83: 2191-2197

14. Laulederkind SJF, Bielawska A, Raghow R, Hannun YA and Ballou LR (1995) Ceramide induces interleukin 6 gene expression in human fibroblasts. J. Exp. Med. 182: 599-604

15. Obeid LM, Linardic CM, Karolak LA and Hannun YA (1993) Programmed cell death induced by ceramide. Science 259: 1769-1771

16. Pushkareva M, Obeid LM and Hannun YA (1995) Ceramide: an endogenous regulator of apoptosis and growth suppression. Immunol. Today 16: 294-297

17. Pronk GJ, Ramer K, Amiri P and Williams LT (1996) Requirement of an ICE like protease for induction of apoptosis and ceramide generation by REAPER. Science 271: 808-810

18. Verheij M, Bose R, Lin XH, Yao B, Jarvis WD, Grant S, Birrer MJ, Szabo E, Zon LI, Kyriakis JM, Friedman A-H, Fuks Z and Kolesnick RN (1996) Requirement for ceramide-initiated SAPK/JNK signaling in stress-induced apoptosis. Nature 380: $75-79$

19. Haimovitz-Friedman A, Kan CC, Ehleiter D, Persaud RS, McLoughlin M, Fuks Z and Kolesnick RN (1994) lonizing radiation acts on cellular membranes to generate ceramide and initiate apoptosis. J. Exp. Med. 180: 525-535

20. Bose R, Verheij M, Haimovitz A-F, Scotto K, Fuks Z and Kolesnick R (1995) Ceramide synthase mediates daunorubicin-induced apoptosis: an alternative mechanism for generating death signals. Cell 82: 405-414 
21. Jarvis WD, Grant S and Kolesnick RN (1995) Ceramide and the induction of apoptosis. Clin. Cancer Res. 2: 1-6

22. Jarvis WD, Kolesnick RN, Fornari FA, Traylor RS, Gewirtz DA and GrantS (1994) Induction of apoptotic DNA damage and cell death by the activation of the sphingomyelin pathway. Proc. Natl. Acad. Sci. USA

23. Cifone MG, De Maria R, Roncaioli P, Rippo MR, Azuma M, Lanier LL, Santoni A and Testi R (1993) Apoptotic signaling through CD95 (Fas/Apo-1) activates an acidic sphingomyelinase. J. Exp. Med. 177: 1547-1552

24. Cleveland JL and Ihle JN (1995) Contenders in FasL/TNF death signaling. Cell 81: $479-482$

25. Gill BM, Nishikata H, Chan G, Delovitch TL and Ochi A (1994) Fas antigen and sphingomyelin-ceramide turnover-mediated signaling: role in life and death of $T$ lymphocytes. Immunol. Rev. 142: 114-125

26. Smith CA, Farrah T and Goodwin RG (1994) The TNF receptor superfamily of cellular and viral proteins: activation, costimulation and death. Cell 76: 959-962

27. Rothstein TL (1996) Signals and susceptibility to programmed death in B cells. Curr. Opin. Immunol. 8: 362-371

28. Barinaga M (1996) Forging a path to cell death. Science 273: 735-737

29. Kim M-Y, Linardic C, Obeid L and Hannun $Y$ (1991) Identification of sphingomyelin turnover as an effector mechanism for the action of tumor necrosis factor $\alpha$ and $\gamma$-interferon. J. Biol. Chem. 266: 484-489

30. Schutze S, Potthoff K, Machleidt T, Berkovic D, Wiegmann $K$ and Kronke M (1992) TNF activates NF- $\kappa$ B by phosphatidylcholine-specific phospholipase Cinduced "acidic" sphingomyelin breakdown. Cell 71: 765-776

31. Wright SC, Zheng Hand ZhongJ (1996) Tumor cell resistance to apoptosis due to a defect in the activation of sphingomyelinase and the $24 \mathrm{kDa}$ apoptotic protease AP24. FASEB J. 10: $325-332$

32. Van Veldhoven PP, Bishop WR, Yurivich DA and Bell RM (1995) Ceramide quantitation: evaluation of a mixed micellar assay using $E$. coli diacylglycerol kinase. Biochem. Mol. Biol. Internat. 36: 21-30

33. Okuda K, Druker B, Kanakura Y, Koenigsmann M and Griffin JD (1991) Internalization of the granulocyte-macrophage colony-stimulating factor receptor is not required for induction of protein tyrosine phosphorylation in human myeloid cells. Blood 78: 1928-1935

34. Chan $\mathrm{H}$ and Aggarwal BB (1994) Role of tumor necrosis factor receptors in the activation of nuclear factor $k$ B in human histiocytic lymphoma U-937 cells. J. Biol. Chem. 269: 31424-31429

35. Munker R, DiPersio J and Koeffler P (1987) Tumor necrosis factor: Receptors on hematopoietic cells. Blood 70: 1730-1734

36. Gulbins E, Bissonnette R, Mahboubi A, Martin S, Nishioka W, Brunner T, Baier G, Baier-Bitterlich G, Byrd C, Lang F, Kolesnick R, Altman A and Green D (1995) Fas-induced apoptosis is mediated via a ceramide-initiated RAS signaling pathway. Immunity 2: 341-351

37. Kolesnick RN, Haimovitz-Friedman A and Fuks Z (1994) The sphingomyelin signal transduction pathway mediates apoptosis for tumor necrosis factor, Fas and ionizing radiation. Biochem. Cell. Biol. 72: 471-474

38. Hannun YA (1996) Functions of ceramide in coordinating cellular responses to stress. Science 274: $1855-1859$
39. Pagano RE, Martin OC, Kang HC and Haugland RP (1991) A novel fluorescent ceramide analogue for studying membrane traffic in animal cells: accumulation at the golgi apparatus results in altered spectral properties of the sphingolipid precursor. J. Cell. Biol. 113: 1267-1279

40. Mathias S, Dressler KA and Kolesnick RN (1991) Characterization of a ceramide-activated protein kinase: stimulation by tumor necrosis factor alpha. Proc. Natl. Acad. Sci. USA 88: 10009-10013

41. Goldkorn T, Dressler KA, Muindi J, Radin NS, Mendelsohn J, Menaldino D, Liotta D and Kolesnick RN (1991) Ceramide stimulates epidermal growth factor receptor phosphorylation in A431 human epidermoid carcinoma cells. J. Biol. Chem. 266: 16092-16097

42. Wolff RA, Dobrowsky RT, Bielawska A, Obeid LM, Hannun YA (1994) Role of ceramide-activated protein phosphatase in ceramide-mediated signal transduction. J. Biol. Chem. 269: 19605-19609

43. Hohmann H-P, Remy R, Pöschl B and van Loon APGM (1990) Tumor necrosis factors- $\alpha$ and $-\beta$ bind to the same two types of tumor necrosis factor receptors and maximally activate the transcription factor NF- $k$ B at low receptor occupancy and within minutes after receptor binding. J. Biol. Chem. 265: 15183-15188

44. Chaturvedi MM, La Pushin Rand Aggarwal BB (1994) Tumor necrosis factor and lymphotoxin. J. Biol. Chem. 269: 14575-14583

45. Yao B, Zhang Y, Delikat S, Mathias S, Basu S and Kolesnick R (1995) Phosphorylation of Raf by ceramide-activated protein kinase. Nature 378: 307 310

46. Dressler KA, Mathias A and Kolesnick RN (1992) Tumor necrosis factor- $\alpha$ activates the sphingomyelin signal transduction pathway in a cell-free system. Science 255: 1715-1718

47. Andrieu N, Salvayre R, Jaffrézou JP and Levade T (1996) Comparative study of the metabolic pools of sphingomyelin and phosphatidylcholine sensitive to tumor necrosis factor. Eur. J. Biochem. 236: 738-745

48. Chatterjee S (1994) Neutral sphingomyelinase action stimulates signa transduction of tumor necrosis factor- $\alpha$ in the synthesis of cholesteryl esters in human fibroblasts. J. Biol. Chem. 269: 879-882

49. Linardic CM and Hannun YA (1994) Identification of a distinct pool of sphingomyelin involved in the sphingomyelin cycle. J. Biol. Chem. 269: $23530-23537$

50. Liu Z-G, Hailing H, Goeddel DV and Karin M (1996) Dissection of TNF receptor 1 effector functions: JNK activation is not linked to apoptosis while NF- $\kappa$ B activation prevents cell death. Cell 87: 565-576

51 Brogi A, Strazza M, Melli M and Costantino CE (1997) Induction of intracellular ceramide by interleukin- $1 \beta$ in oligodendrocytes. J. Cell Biochem. 66: 532-541

52. Sillence DJ and Allan D (1997) Evidence against an early signalling role for ceramide in Fas-mediated apoptosis. Biochem. J. 324: 29-32

53. Preiss J, Loomis CR, Bishop WR, Stain R, Niedel JE and Bell RM (1986) Quantitative measurement of $s n$-1,2-diacylglycerols present in platelets, hepatocytes, and ras- and sis-transformed normal rat kidney cells. J. Biol. Chem. 261: $8597-8600$ 